\title{
POLISH VETERANS OF THE POLISH ARMED FORCES IN THE WEST: WHO DECIDED TO EMIGRATE TO THE USA AND CANADA AFTER WORLD WAR II - AN ORAL HISTORY PERSPECTIVE
}

\author{
Kamil Kartasiński ำ http://orcid.org/0000-0003-1245-0319 \\ University of Silesia, Katowice
}

\begin{abstract}
The aim of this paper is to characterize the generation of Polish veterans of the Polish Armed Forces in the West, who emigrated to the USA and Canada after 1945 in an oral history perspective. The author, using interviews conducted with the veterans, tries to show the motives of emigration to the USA and Canada, the first years of veterans' life in exile and reflection that accompanies veterans at the present time. The author of the article tries to recognize and capture the meanings contained in the veterans' emigre stories, using the oral history workshop on the basis of the analyzed sources.
\end{abstract}

Keywords: Oral history, Polish Armed Forces in the West, emigration.

On 10 July 194728 banners of the Polish Armed Forces in the West were blessed at the Westminster Cathedral, which are then deposited at the Sikorski Institute. The laying of banners is a symbolic date of the demobilization of the Polish Armed Forces (PAF). For thousands of Poles serving alongside the Western Allies, a certain stage in life, begun in September 1939, ended. Polish soldiers then had to take one of the most important decisions in their lives: return to Poland ruled by communists, or stay in exile in culturally foreign countries. As Mieczysław Nurek writes:

facing the necessity of solving the fundamental dilemma in the existential dimension for many Polish Armed Forces soldiers in the West, one of the most dramatic questions in life - to come back or not come back, many of them have been forced by Tymczasowy Rząd Jedności Narodowej $^{1}$ to give themselves a negative answer. In total, more than half of the 250,000 serving

1 Tymczasowy Rząd Jedności Narodowej (Provisional Government of National Unity) was a government formed by a decree of the State National Council (Krajowa Rada Narodowa) on 28 June 1945. 
in the PAF in the West, recognized that they could not return to Poland, whose freedom and democratic freedoms were rushed in a ruthless manner by the new authorities. News about the terror, which was also the source of witnesses from the Polish escapees, caused that many PAF soldiers were forced to stay in exile. ${ }^{2}$

In exile according to estimated data, about 120,000-140,000 soldiers of the Polish Armed Forces in the West remained. What should be explained by such a high percentage of Polish soldiers who remained in exile? This was due to a number of factors that Jerzy Adam Radomski mentioned in his work and are worth mentioning here:

Diametrically, socio-political changes in Poland, marked by changes in revolution, the negative attitude of Polish emigration centers to the then authorities in Warsaw and their propaganda influenced significantly for making decisions about permanent settlement abroad. A large percentage of Polish soldiers came from the eastern provinces, which were plundered by the USSR with the approval of the Tehran and Yalta and Potsdam conferences. These Polish soldiers believed that they had no reason to come back, afraid of reprisals when they returned to their families. On the other hand, some of the soldiers decided, for purely material reasons, to wait through the difficult period of rebuilding the country and settle in the economically developed countries, and at the same time the possibilities of emigrating to many European and nonEuropean countries were opened. ${ }^{3}$

For Polish soldiers who decided to stay in exile, the first place of residence was Great Britain. Polish soldiers who remained in the British Isles joined the Polish-created Polski Korpus Przysposobienia i Rozmieszczenia (Polish Resettlement Corps), established at the turn of August and September 1946 by the British government. The Corps was to serve the demobilization of the PAF in the West, and the right to its entry had soldiers serving before 1 June $1945 .{ }^{4}$ A certain percentage of former PAF soldiers in the West, treated their stay in the British Isles as a transitory direction of emigration. Polish soldiers emigrated from Great Britain, first of all to the countries of the British Commonwealth, the Americas, Africa and the countries of Western Europe. In this article I would like to focus on the issue of emigration of former soldiers of the Polish Armed Forces to the USA and Canada.

Shortly after the World War II, Polish emigration to the USA was limited. Thanks to the efforts of Polish organizations, a group of 70 Polish children, orphans and halforphans from Mexico was brought to the United States on 2 February 2 1947. During the Congress of the Polish National Union in Cleveland, 29 August 1947, a resolution was adopted demanding that the U.S. government accept 100,000 dips into the United States. Until now, dipies from the American occupation zone of Germany and those invited by U.S. citizens or the U.S. consular office had priority to travel to the USA.

It was created as a coalition government between the Polish Communists and Stanisław Mikołajczyk's faction.

M. Nurek, Gorycz zwycięstwa. Los polskich sit zbrojnych na Zachodzie po II wojnie światowej 1945-1949, Gdańsk 2009, p. 623.

3 J. A. Radomski, Demobilizacja Polskich Sit Zbrojnych na Zachodzie w latach 1945-1951, Kraków 2009, p. 107.

4 W. Leitgeber, Polski Korpus Przysposobienia i Rozmieszczenia w świetle dokumentów brytyjskich [in:] Mobilizacja uchodźstwa do walki politycznej 1945-1990, Londyn 1995, pp. 58-59. 
Thanks to the efforts of Karol Rozmarek, President of the Polish American Congress (KPA) and Vice President Ignacy Nurkiewicz, the American Congress passed a new Displaced Persons Act in August 1948. According to this law, more than 341,000 people could emigrate to the United States. The act was in force until 1952 and many former soldiers of the Polish Armed Forces in the West also benefited from it. ${ }^{5}$

In August 1946, the Canadian government asked General Wladyslaw Anders for help to send 4,000 soldiers of the Polish Armed Forces for agricultural work in Canada. From July 1947, Poles from various refugee camps, headed by the International Refugees Organization, began to emigrate to Canada. They were mostly diphiles. By 31 December 1951, the IRO had settled 46,961 Poles in Canada. After 1951, Canada continued to receive demobilized PSZ soldiers, former POWs and prisoners who refused to return to the country ruled by communists. In total, by 1952 , more than 55,000 people were received and settled in all the provinces of Canada. ${ }^{6}$ I would like to present the history of the soldiers of the "The Second Great Emigration" using the oral history method. ${ }^{8}$

Oral history, as Anna Niderla writes: "it consists in collecting eye-witness testimonies of history - recording memories of the past of people involved in the history of their country, in a significant event for the nation and society, as well as recording memories of "ordinary people." "9 The oral history method is not intended to present "great history." Instead, it focuses on presenting personal memories of the interlocutor's life, which he or she considers worth presenting. Human memory is a kind of archive in which information from the past and one's own experience are selected and stored and, if necessary, extracted. It should be stressed, however, that the "stock" of such an archive is very often subject to numerous changes. The more time elapses from the events described by the interlocutor, the smaller the factual value of the relation becomes. ${ }^{10}$ The present is also extremely important, which significantly influences the perception of one's own past by an individual. ${ }^{11}$

As Piotr Filipkowski rightly remarked:

5 J. A. Radomski, Demobilizacja Polskich Sit Zbrojnych, p. 170; L. Pastusiak, Polska-Stany Zjednoczone w latach 1945-1947, Warszawa 1990, p. 100.

${ }^{6}$ J. A. Radomski, Demobilizacja Polskich Sit Zbrojnych, pp. 168-169; L. Pastusiak, Polska-Kanada. Kraje odległe a jednak bliskie, Torun 2002, pp. 100-107.

7 The term 'The Second Great Emigration' refers to post-war emigration and was first used in the work of A. Friszke, P. Machcewicz and R. Habielski, Druga wielka emigracja 1945-1990, Warszawa 1999. Of course, it refers to the Great Emigration of Poles after the November Uprising (1830-1831).

8 The historian Allan Nevins is considered to be the father of oral history. In 1948, he initiated Columbia University in New York, the world's first program of oral history, aimed at recording and archiving oral accounts of US history. It is worth mentioning, however, that Herodotus, considered the "father of history," used oral relations when he described the history of Greece.

9 A. Niderla, Historia mówiona jako metoda badawcza [in:] Historia mówiona w świetle nauk humanistycznych i społecznych, eds. S. Niebrzegowska-Bartmińska, J. Szadura, M. Szumiło, Lublin 2014, p. 40.

10 P. Filipkowski, Historia mówiona i wojna. Doświadczenia obozu koncentracyjnego w perspektywie narracji biograficznej, Wrocław 2010, p. 22.

11 A. Niderla, Historia mówiona jako metoda badawcza, p. 40. 
Oral history is not primarily a search for new facts, but rather an interpretative event, in which the interlocutor must condense his or her story to a few hours long relation, selecting stories, deciding - consciously and not - what and how to tell. The interview is a recollection in the present of the testimony of the past, written in the memory of the present. It is an act that depends both on the moment in which it takes place and on the history to which it refers. ${ }^{12}$

People who tell a war story usually remember it very personally. They are often mistaken about details, chaotic, but almost always authentic. What emerges from their relationship is what can be called the true image of war (and what followed), seen from the position of an ordinary soldier.

My main source on which I would like to base my article are oral relations of veterans of the Polish Armed Forces in the West, which are in the Archive of the Institute of National Remembrance in Katowice. ${ }^{13}$ I would like to write a few words about the source base I have used here. The collection of 31 film notations with veterans or Sybiraks was carried out in the period 5 July-4 August 2011 in American Chicago and Canadian London and Toronto ${ }^{14}$ by the employee of Institute of National Remembrance, dr Mirosława Sikora, and director Sławomir Górski and cameraman Piotr Niemcewicz. The collected group of veterans represented the I and II Polish Corps, the air force and the navy. Conversations with veterans were carried out in the field of factography ${ }^{15}$ as well as comments and emotions. ${ }^{16}$ Interviews with witnesses of history lasted on average for 2-3 hours and were mostly conducted at the home of interlocutors. The material I used was worked out by me earlier as part of a research internship at the Katowice branch of the Institute of National Remembrance. For the purposes of the article, I chose the 11 most interesting, in my opinion, testimonies of veterans, which I would like to submit here my own analysis using the oral history workshop. ${ }^{17}$ The article has been divided into three parts by me. In the first one I present the motives that the veterans were guided by choosing the fate of the emigrant. In the second part, I present the way of veterans to the US and Canada and the beginning of their lives in the new reality. In the third and last part, I present the diverse reflections of veterans that arise after a few decades of life in exile.

12 P. Filipkowski, Historia mówiona i wojna [in:] Wojna. Doświadczenie i zapis - nowe źródła, problemy, metody badawcze, eds. S. Buryła, P. Rodak, Kraków 2006, p. 15.

13 When writing the article, I used also a person interviewed by myself in 2014 in the USA, with Michał Lasek, paratrooper of the $1^{\text {st }}$ Independent Parachute Brigade.

14 The places mentioned here are the main Polish centers (Polonia) in the USA and Canada.

15 Personals, family home, education, youth in the Second Polish Republic, relations between Poles and other nationalities, World War II, 1945 and the decision to emigrate to the USA/Canada.

16 Opinions on the Second Polish Republic, the drama of war, moral aspects of the war, Western allies against the Polish authorities in London, veterans of the PAF in the West in the Polish People's Republic era, the evaluation of the Third Polish Republic.

17 When writing this article, I pattern myself upon Piotr Filipkowski's work, Historia mówiona $i$ wojna. Doświadczenia obozu koncentracyjnego w perspektywie narracji biograficznej. 


\section{MOTIFS OF EMIGRATION}

Collected footage allows you to familiarize yourself with the very diverse causes of emigration. The main motives that the veterans were guided by were:

Patriotic attitudes - deep love for pre-war Poland; upbringing, which they received from their parents ${ }^{18}$ and brought out during school education; deep hostility to communism.

Economic factors - most of the veterans grew up in villages with large families, who could not provide each member of the family with the appropriate material status in Poland. Emigration itself was an opportunity for them to improve their own economic and social status. Veterans also received information about the complete destruction of family property or about finding a family place outside of post war Poland.

Family motives - death of close family members; family breakdown as a result of the war; willingness to start a family for people who were unmarried.

Educational motives - a large group of veterans began specialized courses after the war or began studying at Western universities, which gave the opportunity to obtain the right skills or education to find a new, western labor market.

All the motifs I have mentioned are more or less related to each other in the veteran testimonies which I have studied. Let us now proceed to the analysis of three fragments of Memories of veterans - Wiktor Kobarde, ${ }^{19}$ Edmund Bordecki, ${ }^{20}$ Jan Ejbich, ${ }^{21}$ and Andrzej Dębicki, ${ }^{22}$ who motivated their decision to stay in exile in the following way:

There were thoughts about what to do with myself after the war. I will not come back to Poland, absolutely there. I once wrote to my family that it was then Russia, the Belarusian SSR. And I wrote to my family because they told me that if you want to come back, write letters. And I was long after the war in Poland. And they told me during this meeting: "We have not once cried what to write you." They wrote to me, "Remember, you will be sick as in 1940" - what is

18 The veterans' fathers mostly took part in battles during the World War I or during the PolishBolshevik war.

19 Wiktor Kobarde was born in 1923 in the Vilnius region. In 1940 he was deported to Siberia, from where he escaped with the Anders Army. He was a soldier of the Second Polish Corps, serving in artillery. After the war, he emigrated to Canada and settled in London. He died in 2017.

20 Edmund Bordecki was born in 1924 in Królówka in the Tarnopol province. In 1940 he was deported to Siberia, from where he escaped with the Anders Army. He was a soldier of the Second Polish Corps, he served in the infantry. After the war, he emigrated to Canada and settled in Toronto. He died in 2012.

${ }_{21}$ Bogdan Jan Ejbich was born in 1916 in Saratov in the Saratov region (Russia). In the September Campaign of 1939, he served in the rank of second lieutenant in the technical projection of the 1st Air Regiment. He served in the $304^{\text {th }}$ squadron of bombers. After the war, he emigrated to Canada with his wife and children and moved to Toronto. He died in 2013.

22 Andrzej Dębicki, was born in 1920 in Krakow in the Krakow province. In 1940 he was deported to Siberia, from where he escaped with the Anders Army. He was a soldier of the Second Polish Corps, he served in artillery. After the war, he emigrated to Canada and settled in London. He died in 2018. 
mean - they would arrest me. Some of polish soldiers went home in Poland and none of them returned, they deported straight to Siberia." ${ }^{23}$

The manner of constructing the story of Wiktor Kobarde is chaotic, pointing to the still vivid emotions associated with the decision to emigrate. The interviewer, before returning to Poland, tried to conduct an appropriate interview, drawing information from people closest to him whom he could trust. The word "absolutely" used in his speech, additionally underlined by appropriate modulation of the voice, shows that the interlocutor, after receiving an encrypted message from his family, "you will be sick as in $1940 " 24$ he made the final decision not to return to Poland. The rightness of his choice, Kobarde additionally emphasizes the information about the return of other soldiers to the former areas of the Second Polish Republic controlled by the communist authorities and their forced deportation to Siberia. Undoubtedly, his decision was also influenced by the fact of deportation to Siberia in 1940 and his experience with the Soviets.

I had grudge for these Allies, that really at the end, the victory parade was, they did not take Poles. The French, English, Americans were. Poles did not take ... They did not take anybody from our army because they said - "you can come back to Poland. There is also a parade in Poland." And we could not go back to Poland. I had to emigrate, I had two married sisters. They went to Poznan, they gave them former German farms. I had to start in Poland from nothing. I thought - I read a lot about Canada, I thought about Canada or America. And I was healthy and strong. You know, I was not exhausted in the army, because we were always on these carriers, we did not have to go anywhere on foot. Always under the protection of this armor, there was not a large armor, but the armor was these carriers. I came here [to Canada], I can go and turn the mountains over. ${ }^{25}$

In Bardecki's testimony, three motives of staying in exile can be distinguished. The first thing, without being told explicitly, is the subordination of Poland to the Soviets: "and we could not go back to Poland". ${ }^{26}$ The inability to return to their homeland connects with Bardecki's regret at the Western Allies about the inability of Poles

${ }^{23}$ From the report of Wiktor Kobarde available at the IPN Archives in Katowice, reference number Kobarde Kas. 20-2, Kas. 21-1.

24 These are, of course, four mass deportations carried out by the Soviets in 1940-1941. The deportations were carried out on Poles living in the territory of the Second Polish Republic, annexed by the USSR after 17 September 1939. The deportations carried out by the Soviet occupier were carefully prepared and planned. The deportation covered the families of military settlers, peasants and forest service workers and their relatives. See J. Siedlecki, Losy Polaków w ZSRR w latach 1939-1986, Gdańsk 1990.

25 From the report of Edmund Bardecki, available in the Archives of the Institute of National Remembrance in Katowice, the Bardecki reference number Kas. 24-3, Kas. 25-1, Kas. 24-1.

26 As Krzysztof Tochman writes: "All [Polish soldiers] returning from the West to Poland controlled by the communists and the Soviet Union were, according to the regime factors, serious threats to the totalitarian system in the country ... As early as 1947, all the soldiers of the Polish Armed Forces - reserve soldiers demobilized from various formations - who returned to the country, were systematically checked and supervised by the civilian security apparatus." K. Tochman, Rozpracowywanie żolnierzy Polskich Sit Zbrojnych na Zachodzie przez komunistyczny aparat represji na wybranych przykładach cichociemnych [in:] Politycznie obcy! Żotnierze Wojska Polskiego w zainteresowaniu komunistycznego aparatu represji i propagandy w latach 1944-1945, eds. B. Polak, P. Skubisz, Szczecin 2011, s. 131. 
to participate in the victory parade. ${ }^{27}$ The mention of other nationalities by Bardecki, who took part in the parade, aims to underline the injustice that met a Polish soldier for his efforts and blood sacrifice on the fronts of World War II. The second motive is the economic issue. The Bardecki sisters somehow were economically secured by receiving a former German farm. Bardecki, serving so many years in the army and staying abroad did not have such a possibility. "I had to start with nothing" shows the lack of any economic prospects in Poland by him. The last, perhaps the most interesting factor emphasizing the choice of the emigrant's fate is the personal faith of the Conversor in his own abilities "and I was healthy, strong" "I can go and turn the mountains over." His certainty was additionally emphasized by appropriate gestures. Bardecki modulated his voice very firmly and clenched his hands in fist, showing his will to prove to his listeners the truth of his story.

I sent parcels to my mother during II WW. My mother did not know that these packages came from me. I did not know that my father and brother died. But after the war, I could not come back yet, because I applied to Air Ministry for the continuation of my polytechnic studies. And I had the privilege that I finished my flights in time and my application was accepted. I had technical school facilities, I already knew, integrals, differentials I had in my finger, because I learned all the time ... Also, I could not think about returning to Poland, I had to finish the polytechnic. I would come back to Poland as an educated engineer. With a full degree and a lot of help for my country. But in the meantime, letters from Poland began to be claimed. The first letter about the death of my father, then my brother, then I learned about the arrest of Skalski my friend, and then the arrest of others, this information came. I knew I did not have a chance. In the meantime, I still recived letters from my mother, to 1952 the last letter. I did not have the right to go back. She wrote briefly - "not yet," I knew what it meant "not yet." 28

Emigration to Canada in the case of Jan Ejbich was motivated by three factors. The first was the study undertaken by the Interlocutor, which he wanted to complete before returning to Poland to serve his knowledge and experience in motherland. At the stage of study, he still considered returning to his homeland. The decisive factors in staying in exile were his regular correspondence with his mother, who informed her son about the dangers of his return to the country. He was also influenced by information about the arrests of other pilots. Observing the behavior of the Interlocutor during the conversation, it is difficult to say which of the motives he mentioned was the most crucial for him. Ejbich kept his narration calmly, showing no emotion at any of the premises mentioned. This may be due to the fact that the decision on emigration for the Interlocutor was spread over several years. He was preparing for it gradually, and thus it was easier for him and his wife to make the final decision to tie their life with Canada.

I came to Canada on April 15, 1955. In England, for some time I worked in a very good company in Devon. We decided with my wife to stay in England, not to go to Poland, it was out of

27 The London Victory Celebrations of 1946 were British Commonwealth, Empire and Allied victory celebrations held after the defeat of Nazi Germany and Japan in World War II. The celebrations took place in London on 8 June 1946.

${ }^{28}$ From the report of Jan Ejbich, available in the Archives of the Institute of National Remembrance in Katowice, the Ejbich reference number Kas. 24-1, Kas 24-2. 
the question. We stayed in England, we had a very nice house, my wife and me had a job. Devon is lovely, the temperature was a turbulent year, and we have only succumbed to the pleas and pleas of my two officers who emigrated from Italy for a contract to cut down trees in Quebec, Canada. They gave me money for the journey and I decided to emigrate to Canada with my wife. My stimulus for this was my health, which began to fall. The stomach, also after my arrival in Canada, healed me completely. The wife had eczema, also completely cured in Canada, my daughter had asthma attacks that were completely over in Canada, so we were in cloud nine. And we settled in Hamilton. ${ }^{29}$

Andrzej Dębicki and his wife lived in Great Britain for several years. ${ }^{30} \mathrm{He}$ had a good job and made a fortune. He did not have to worry about keeping his family. The emigration to Canada was determined primarily by his family's health, which he emphasized by mentioning three diseases - asthma, stomach problems and eczema - which afflicted his family in England. The offer of friends from the army was of secondary importance in his case, because financial issues were no problem for him. Canada for Dębicki is first and foremost a place thanks to which he managed to improve his family's health.

\section{FIRST YEARS IN THE USA / CANADA}

The decision to emigrate was only the beginning of a long way for a Polish emigrant. The former PAF soldiers in the West took several long years to achieve a certain social status. The Poles, when deciding to live in a culturally and morally foreign country, encountered a number of problems that they overcame with their resourcefulness, diligence and help from other fellow countrymens. In the memories of the veterans, the first years of life in exile were particularly striking. It was a time for them to look for a well-paid job, acclimatize to a new community, improve their language skills and apply for American or Canadian citizenship. The factors I have mentioned were the key moments of their emigration biography and appear in all veterans' memories. In the first years of emigration, the first years of difficulties were compensated by higher earnings, improvement of material status, assumption or extension of own family and a sense of fulfillment. In this part of the article, I would

29 From the report of Andrzej Dębicki, available at the IPN Archives in Katowice, reference number Dębicki Kas. 18-2, Kas. 19-1.

30 At the end of the war in the British Isles there were about 95,000 Poles, of which about 74,000 were soldiers and 21,000 civilians. A characteristic feature of the Polish diaspora in Great Britain was its socio-professional structure, which was mostly the elite of the Polish community (professors, state officials, former landowners, etc.). See J. A. Radomski, Demobilizacja Polskich Sił Zbrojnych, pp. 155-156. 
like to present the memories of the next veterans they are Rudolf Detlaff, ${ }^{31}$ Michat Lasek, ${ }^{32}$ and Kazimierz Teper. ${ }^{33}$

So I stayed longer in England. And I see that the chance is to go to America, the chance for Canada was also, very easily, I still graduated an agricultural school. I applied to the USA. But there had to be someone from the US who worked there and would help me at the beginning. And one old lady "adopted" me. And when I came to the USA, my sponsors call this old lady and ask where she was. And she said to them, "I just signed and I do not want him!" But finally she came and took me to her cottage for four days. Her daughter was an attorney, she took me to the shoe factory and found a job there. And I had to work, and here I made some 30,000 dollars a year. So here I came and sat here. ${ }^{34}$

The beginning of a new life in the USA was for Rudolf Detlaff, after many years of the events he presented, a humorous accent. He comes to the USA almost on spec. He does not know the person who will help him in the first months of his stay in exile. The situation he was meeting just after arriving in Chicago was a big surprise for him at the time and a cause for concern. However, from the perspective of several decades, the memory evolved into a humorous anecdote, which the Interlocutor talks with a smile on his face. His relation also shows the motive of quickly finding a good job and satisfying earnings that contributed to almost all memories, which contributed to the fact that "So here I came and sat here."

In England, a few years after the war began a hard life. For me, there was no other way out and I started looking for opportunities in another country. I went first to the consul in South Africa, but he said that they only need engineers. And I have a US or Canada. However, I hoped it would be America. And so it happened, I got a sponsor and I came here in 1951. It was not until a man came here that he saw his whole life. I was glad that I was here. I told my wife that here he will be "life like in first-class" and we will manage. I started working in China Town in New York, where I worked 12 hours a night. And because in England I completed a mechanic course - locksmith, I did it on a lathe. I was getting \$ 1.05 an hour. The first thing I bought was clothes and dressed like a lord! Then I bought a cigarette case, because in those times everyone smoked. Live not to die, life was paramount, and food was plentiful. ${ }^{35}$

31 Rudolf Detlaff, born in 1921 in Kashubia. He served in the Wehrmacht, and then in the I Polish Corps, serving in armored troops. After the war, he emigrated to Chicago, USA. He died in 2012. In the case of Detlaff, who had previously served in the Wehrmacht, it is worth mentioning that most Poles who had previously served in the German army decided to return to Poland after the World War II. What is important, they also did not encounter mass repressions from the communist authorities. See R. Kaczmarek, Polacy w Wehrmachcie, Kraków 2010, pp. 371-385.

32 Michał Lasek, born in 1923 in Przeworsk, in the Podkarpackie Voivodeship. He was exiled to Siberia in 1940. He served in the 1st Independent Parachute Brigade. After the war, he emigrated to New York in the USA. He died in 2015.

33 Kazimierz Teper, born in 1923 in Rabka Zdrój, in the Lesser Poland Voivodeship. As a child, he was sent to forced labor in Germany. In 1944 he joined the II Polish Corps. After the war he emigrated to London, Canada. He died in 2013. In the case of Teper, it is worth mentioning that by August 1944, $1,400,000$ Polish civilians had been registered as forced laborers on the territory of the Greater German Reich. See C. Łuczak, Praca przymusowa Polaków w Trzeciej Rzeszy i na okupowanych przez nia terytoriach innych państw (1939-1945), Poznań 2001.

${ }^{34}$ From the report of Rudolf Detlaff, available at the IPN Archives in Katowice, reference number Dettlaf Kas. 10-2, Kas. 11-1.

35 From Michał Lasek's report, author's collections. 
For Michał Lasek, after his experiences in the pre-war Polish countryside and life in Great Britain, the United States turned out to be a paradise. In his memoirs the question of food and dress was very important. The emphasis of these two matters is closely related to his personal experiences - living in the Polish countryside before 1939, and staying in Siberia, where hunger and the lack of appropriate clothes were particularly painful. Life and work in the US allowed him to meet these basic needs and became for him a determinant of his own concept of luxury. Therefore, in his relationship there is so much enthusiasm for describing his life in the US ("first-class," "live not to die"). Lasek also enters into social conventions (smoking), which were previously unavailable to him due to his peasant status.

When I came to London in Canada in 1952, where there was terrible unemployment. So I did not have any relatives or friends or work, I did not know what we would start. My wife found a job in a lingerie factory and her manager offered me a job. I came to boss factory and thought what I would do here. And she says to me: "No matter what. You will wash the toilets, or sweep the floor." And I started my work at the beginning. As I worked earlier in an English bank, I was later promoted to an accountant and then accepted people to work in this factory. And that's how I worked, but I did not get Canadian citizenship yet. More a child was born to me, and I had such a modest apartment, I did not have enough money, I walked about 2.5 kilometers to work, one way. My wife was, not very healthy, so I asked for a manager increase. And he says - sorry we cannot give you. And I say - reason? Because you do not have Canadian citizenship. And I tell him - this is discrimination, because of this, I give up and leave. And so I did. I went to another factory. Later I worked probably 12 years in the second factory, I got a little on my feet, I made a house, I bought a house with a garden, I had a children. My wife was very ill all the time because she got a nervous breakdown so I had to change my job again, but I always found a new one work. When I sent the application to five factories, everyone accepted me. ${ }^{36}$

For Kazimierz Teper, the beginnings on the Canadian land were not the easiest ones. The problem with finding a job and the lack of any friends in Canadian London was a cause for concern for him, which was permanently outlined in his memories. The memory of Teper, however, shows that thanks to a little luck and his own diligence and resourcefulness, he was able to find the right job. He was also not afraid of risking changes to improve his status when his wife had health problems. It can be seen that happiness in the meaning of the Interlocutor was manifested in the form of good employment, building your own home and starting your own family and having children.

\section{REFLECTIONS}

Staying for most of his life in exile, forced many veterans to reflect on their own lives. In the material I researched, the considerations of veterans were mainly about the characteristics of American Polish diaspora, family relations, bitterness due to

${ }^{36}$ From the report of Kazimierz Teper, available at the IPN Archives in Katowice, reference number Teper Kas. 20-1. 
betrayal of Western allies and reflection on the achievement of an aged age. The following reflections were not predetermined by the interviewers. They appeared spontaneously and evoked extreme emotions. The veterans in the recordings showed anger, aversion, contempt, but also cheerfulness, a sense of fulfillment and security. The issues I am most concerned about reflect relationships from Zygmunt Biernat, ${ }^{37}$ Zbigniew Gondek, ${ }^{38}$ Mieczysław Lutczyk, ${ }^{39}$ and Henryk Starczewski ${ }^{40}$.

Means these are possibilities, if you have a knack on your head, I came here - as the boy from the village says. I ran a grocery store here for 30 years! A small shop! I educated three children who went to Catholic schools. I had to pay for their education. I could educated three children from this little shop and today I am not a poor man! I have never tried to do this property today or tomorrow. I did it slowly and I achieved it. People who came here to the US, like from the Polish Army, but not only the army, also people who were in Germany, all together took to work. Even some of them managed to get to good work. As one of them had a little education, or something, he got a better job. You did not see a Pole in the gutter, you did not see a Pole go down the street and blaspheme. This whole company was meeting. The airmen's ball at Pearl House, 800 people! I will not say that they did not drink, but the drunk did not see. And if he drank too much, he took it to the car and drove it home. Seriousness, kindness, and so that we built the image of a Pole in the USA. Not like now, if I go to a Polish store, it will not go out without a whore and fuck! Only one to another says so! I even noticed why you would not throw him away! And the latter "because he is only with me, he is my friend." I would not admit to him that he is my friend. You see what we have been building here for so many years and I will not say that everyone, but one apple will spoil the whole barrel. And these people here are hurting us. ${ }^{41}$

Biernat feels proud of the decision to emigrate to the USA. In his relationship, he emphasizes the fact that being a "boy from the village" he managed to earn a good fortune and enabled his children to obtain higher education. He emphasizes his current status very emotionally, using the denial "today I am also not a poor man," which aims to emphasize his social and economic position. Biernat believes in the sense of hard work, realizes that success can only be achieved if you are patient and persistent. In Biernat's testimony, it is characteristic to compare the "old" post-war polish emigration, which he himself represents with the "new" polish emigration, which has

37 Zygmunt Biernat was born in 1920 in Koło in the Greater Poland Voivodeship. During World War II, he served in the Independent Carpathian Rifle Brigade in the infantry. After the war, he emigrated to Chicago in the USA. He died in 2014.

38 Zbigniew Gondek was born in 1924 in Przemyśl. In 1940 he was deported to Siberia. He served in the II Polish Corps in the infantry. After the war, he emigrated to Toronto, Canada, where is still living.

39 Mieczysław Lutczyk was born in 1919 in Ostojów, in the Świętokrzyskie Province. He took part in the September Campaign, later served in the I Armored Division of General Stanisław Maczek. After 1945, he emigrated to Toronto, Canada. He died in 2015.

40 Henryk Starczewski was born in 1916 in Mińsk Mazowiecki, in the Masovian Province. He took part in the September Campaign, was imprisoned by the NKVD, served in the II Polish Corps in artillery. After the war, he emigrated to Toronto, Canada. He died in 2015.

${ }^{41}$ From the report of Zygmunt Biernat, available in the Archives of the Institute of National Remembrance in Katowice, the reference number Biernat Kas. 4-1. 
come to the USA in recent years. ${ }^{42}$ Upbringing, personal culture and respect for others are for Biernat the values that he ruthlessly observed in his life. The Interlocutor is embittered by the present generation of Poles. The curse used in his relationship, I exert his anger and helplessness, because as an older man, although respected in his own community, he cannot do anything. The Interlocutor tries to convey that the individual's behavior can spoil the opinion of the whole community that he and his colleagues have built up over the years in exile in the USA.

I have wishes, that's what we did, we were about 80,90 years old. How many strength veterans we can have? And we are still working. Take our heritage from us! Do it! We help what we can, even now. With us it somehow disappears here. In Toronto, it fades, I'm afraid of it. There are scouts too, I'm afraid of it. I'm afraid of that, that's why we go to school, listen - we tell you, what we know, what you should know what we can do. We'll do it. Take now, now you're starting to do something. For us, 10-15 years is the maximum, as I am 87 , what I can expect. But what are the years? These are numbers. 87 is a number, it can be 78 not. I say so. Turn it over, I do not feel 87 years under any circumstances. I do not say I do not hurt, here or there, I'm sure it hurts. I do not feel for 87 years, damn it is an old plague I am already. ${ }^{43}$

Gondek's reflection focuses on realizing the problem of veterans leaving, who lack the strength to continue their mission. Gondek emphasizes the need to pass the "baton of veterans" heritage to future generations, because time for veterans is flowing inexorably and as he himself recalls for them, " $10-15$ years is the maximum." The question of an old age is for him an attempt to take short philosophical reflections on the subject of lived years. Gondek keeps a sense of humor during the conversation and a distance to himself, defining his own person with a smile, "damn it is an old plague I am already."

So I wanted to say, this matter which lies on my heart as the Allies betrayed us. ${ }^{44}$ They sold us to Stalin. Churchill and Roosevelt, and to this day I have a heart, that I wander in a foreign country and have my adopted homeland, Canada, but Poland is in my heart and I will never forget it. But the same is true of our former president in exile Raczkiewicz, who says that the Allies urged him and pushed him to remove General Sosabowski from the Polish commander 1SBS. How can you think that the president could hear someone what to do with such a soldier who has been in death every second? It means that he would sell Poland also. The second thing they did with my division commander, Maczek. Same. Truth. He was an ordinary worker and he was and worked at the hotel as a waiter. ${ }^{45}$

For Mieczysław Lutczyk, memories of the post-war fate were very painful. The Interlocutor cried and could not say a word when he recalled the situation in which his homeland was found, through the policy of the Allies. Despite many years of emigration in Canada, Poland is still the most important for him and he will never

42 Jan Krawiec describes the problem of the "old" and "new" Polish community in an interesting way in his memoirs. See J. Krawiec, Od Bachórca do Chicago. Wspomnienia, Warszawa 2015.

43 From the report of Zbigniew Gondek, available in the Archives of the Institute of National Remembrance in Katowice, the signature of Gondek Kas. 23-2, Kas. 23-1.

44 For more information on this problem see M. Nurek, Gorycz zwycięstwa.

45 From the report of Mieczysław Lutczyk, available in the Archives of the Institute of National Remembrance in Katowice, the signature of Lutczyk Kas. 13, Kas.14. 
forget her. The emotion that accompanied him was so strong that he had to interrupt the conversation for a moment, then bitterly talk about the unjust treatment of Polish generals who had to earn after the war by doing physical work. ${ }^{46}$ For Lutczyk honor and fatherland were the main values that he followed in his life. Lack of respect for the soldier's honor and love for his homeland were extremely painful for him, even after a few decades from the events he had mentioned.

For me, the location in which I like to live, because it is close to the subway. It's about a 10 minute walk. Also today, when I am going to play a bridge, then I take the queue and the tram, up to Beverly and a bit of a passage. And I've stopped riding, I already gave my driving license, two years ago, because so many crazy people go. And my license plate was a special board with a red brand and veteran. They could still, let's say, they could still blame it was my fault that I was a veteran, that it was. I also decided what for? Why should I murder myself? And I feel good. I move very well, being 95 years old. ${ }^{47}$

Henryk Starczewski does not show high-minded reflections that he could have. e.g. patriotic coloring. For the Interlocutor the most important are "normal" life matters that relate to his place of residence, giving up his driving license, to avoid the hassles and perfect health condition, which he enjoys at the age of 95. His reflection on his own life concerns mundane present matters. It is possible to write that he enjoys moments of his life. Mentioning during the conversation that he was going to play a bridge on the same day, I show that despite the advanced age, he has further plans that he wants to successfully implement.

\section{CONCLUSIONS}

The memories of veterans that have been recorded and written down after a few decades can not be regarded as a priority historical source that will allow to establish new facts in a given issue. The autobiographical space and the way the veterans create their own stories is endless and open. This causes the occurrence in their narratives of numerous factual errors, skipping from topic to topic and chaoticness. The way of creating your story is very often very emotional and personal. Talking emotions during the conversation - crying, joy, euphoria, anger, sorrow, bitterness - it is impossible to give away in any historical source. It can only be personally experienced and seen on a recorded video image. Therefore, the story about her/his memories (oral history) is for the Interlocutors an autobiographical journey in which they take their listener-researcher.

A witness to history sharing my memories and emotions, give to her/his listeners a part of my own past, intimate future and full reflection that appear over the years

46 The fate of Polish generals serving under British command after World War II was described in his book by Szymon Nowak. See S. Nowak, Niechciani generałowie, Warszawa 2018.

47 From the report of Henryk Starczewski, available in the Archives of the Institute of National Remembrance in Katowice, reference number Starczewski Kas. 26-3, Kas 27-1. 
of their lives. The analysis of biographical narrations allows to obtain information that is not present in other source materials, which e.g. escape in diaries or memoirs. Such research is particularly important in the study of the post-war fate of soldiers of the Polish Armed Forces in the West. Talks with veterans, allow to capture many "flavors" of emigre life, present a "vivid" picture of the problems and adversities with which Polish soldiers had to face on Canadian or American land. Finally, let us look at this extraordinary generation, not from the perspective of strictly military fate and in some sense martyrology present in Polish history, but from the perspective of normal post-war life, which lasted for several decades. The article presented by me is only a modest contribution to research, which can certainly bring interesting results. ${ }^{48}$ Jerzy Eilser wrote rightly about historical sources that "it is impossible to divide into more or less valuable source materials. Every source deserves to be taken into account, but at the same time none deserves to be approached without reflection, with uncritical trust." ${ }^{49}$

The difficulty in research lies primarily in the fact that the generation of veterans is very few and it is almost impossible to carry out a reliable and long conversation with these interesting witnesses of history. Researchers must, for the most part, already use sources previously produced and accumulated in the archives of oral history or veterans' organizations. For future researchers it is first and foremost how they will want to interpret them and use them in their research. And this is also the case with this article, in which I tried to recognize and capture the meanings contained in the emigre stories of Polish veterans from the USA and Canada, through their own interpretations and reading these meanings.

\section{BIBLIOGRAPHY}

\section{Sources}

Archive of the Institute of National Remembrance in Katowice.

\section{Literature}

Eisler, J., Relacje z perspektywy badacza PRL [in:] Historia mówiona w świetle nauk humanistycznych i spotecznych, eds. S. Niebrzegowska-Bartmińska, J. Szadura, M. Szumiło, Lublin 2014.

Filipkowski, P., Historia mówiona i wojna. Doświadczenia obozu koncentracyjnego w perspektywie narracji biograficznej, Wrocław 2010.

48 As evidenced by work A. Wylęgała, Przesiedlenia a pamięć. Studium (nie)pamięci na przykładzie ukraińskiej Galicji i polskich „Ziem Odzyskanych”, Torun 2014.

49 J. Eisler, Relacje z perspektywy badacza PRL [in:] Historia mówiona ..., s. 156. 
Filipkowski, P., Historia mówiona i wojna [in:] Wojna. Doświadczenie i zapis - nowe źródła, problemy, metody badawcze, eds. S. Buryła, P. Rodak, Kraków 2006.

Friszke, A., Machcewicz, P., Habielski, R., Druga wielka emigracja 1945-1990, Warszawa 1999.

Kaczmarek, R., Polacy w Wehrmachcie, Kraków 2010.

Krawiec, J., Od Bachórca do Chicago. Wspomnienia, Warszawa 2015.

Leitgeber, W., Polski Korpus Przysposobienia i Rozmieszczenia w świetle dokumentów brytyjskich [in:] Mobilizacja uchodźstwa do walki politycznej 1945-1990, Londyn 1995.

Łuczak, C., Praca przymusowa Polaków w Trzeciej Rzeszy i na okupowanych przez nia terytoriach innych państw (1939-1945), Poznań 2001.

Niderla, A., Historia mówiona jako metoda badawcza [in:] Historia mówiona w świetle nauk humanistycznych i społecznych, eds. S. Niebrzegowska-Bartmińska, J. Szadura, M. Szumiło, Lublin 2014.

Nowak, S., Niechciani generałowie, Warszawa 2018.

Nurek, M., Gorycz zwycięstwa. Los polskich sił zbrojnych na Zachodzie po II wojnie światowej 1945-1949, Gdańsk 2009.

Pastusiak, L., Polska-Kanada. Kraje odległe a jednak bliskie, Torun 2002.

Pastusiak, L., Polska-Stany Zjednoczone w latach 1945-1947, Warszawa 1990.

Radomski, J. A., Demobilizacja Polskich Sit Zbrojnych na Zachodzie w latach 1945-1951, Kraków 2009.

Siedlecki, J., Losy Polaków w ZSRR w latach 1939-1986, Gdańsk 1990.

Tochman, K., Rozpracowywanie żotnierzy Polskich Sit Zbrojnych na Zachodzie przez komunistyczny aparat represji na wybranych przykladach cichociemnych [in:] Politycznie obcy! Żotnierze Wojska Polskiego w zainteresowaniu komunistycznego aparatu represji i propagandy w latach 1944-1945, eds. B. Polak, P. Skubisz, Szczecin 2011.

Wylęgała, A., Przesiedlenia a pamięć. Studium (nie)pamięci na przykładzie ukraińskiej Galicji i polskich „Ziem Odzyskanych”, Toruń 2014. 